\title{
MPRA
}

Munich Personal RePEc Archive

On wage formation, wage flexibility and wage coordination : A focus on the wage impact of productivity in Germany,

Greece, Ireland, Portugal, Spain and the United States

Peeters, Marga and Den Reijer, Ard

29 June 2011

Online at https://mpra.ub.uni-muenchen.de/31102/

MPRA Paper No. 31102, posted 30 Jun 2011 19:00 UTC 


\title{
ON WAGE FORMATION, WAGE FLEXIBILITY AND WAGE COORDINATION
}

\section{A focus on the wage impact of productivity in Germany, Greece, Ireland, Portugal, Spain and the United States}

\author{
Marga Peeters and Ard den Reijer ${ }^{1}$
}

June 2011 - Brussels and Stockholm

\begin{abstract}
This paper discusses the endeavours of policy makers to come to some degree of wage coordination among EU countries, aiming at aligning wage growth with labour productivity growth at the national levels. In this context, we analyse the wage and productivity developments in Germany, the European Union's periphery countries Greece, Ireland, Portugal, and Spain along with the US for the period 19802010. Apart from the contribution of productivity to wages, we take into account the contributions of prices, unemployment, replacement rates and taxes by means of an econometrically estimated non-linear wage equation resulting from a wage bargaining model. We further study the downward rigidities of wages in depth. The findings show that in past times of low productivity, price inflation and reductions in unemployment put significant upward pressure on wage growth, also in the low inflationary period of the 2000s. Greece, Ireland, Portugal and Spain are far from aligning wage growth with productivity growth. German productivity is a major German wage determinant, but surely not the only one. To steer wages, policy makers can effectively use the replacement rate.

Key words: wages, compensation per employee, unit labour costs, productivity, wage formation, wage coordination, labour market, wage flexibility, unemployment, prices, replacement rate, monetary union.

JEL codes: C22, E5, E6, E24, J30.

\footnotetext{
${ }_{1}$ Corresponding addresses: huber@tinamargapeeters.eu and ard.den.reijer@riksbank.se. Marga Peeters has a research sabbatical and the affiliation of Ard den Reijer is the Swedish central bank. The views expressed in this Working Paper are solely the responsibility of the authors and should not to be interpreted as reflecting the views of the Executive Board of Sveriges Riksbank. We welcome any comments or questions, either good or bad.
} 


\section{TABLE OF CONTENTS}

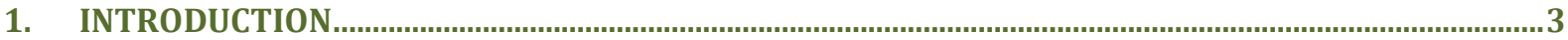

2. LITERATURE BACKGROUND AND STYLISED FACTS …..................................................................

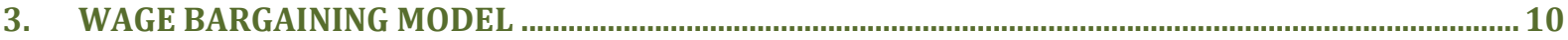

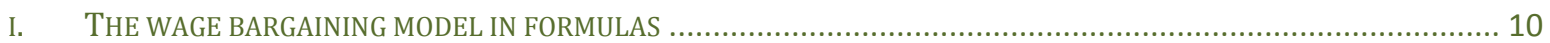

II. AN ECONOMIC INTERPRETATION OF THE WAGE BARGAINING MODEL ................................................. 15

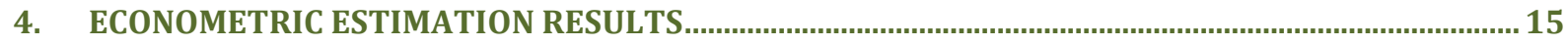

I. THE ESTIMATION STRATEGY, PARAMETER ESTIMATES AND ROBUSTNESS TEST STATISTICS ............................... 16

II. WAGE GROWTH DECOMPOSED INTO PRODUCTIVITY, PRICES, UNEMPLOYMENT AND OTHER DETERMINANTS .......... 18

5. LOW PRODUCTIVITY GROWTH AND DOWNWARD WAGE RIGIDITIES.......................................... 22

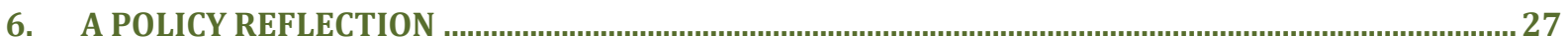

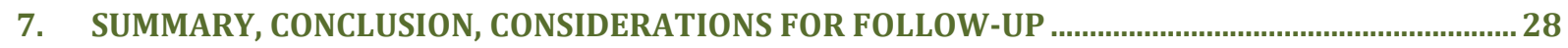

APPENDIX A. DERIVATION OF THE WAGE EQUATION, THE WAGE ELASTICITIES AND THE WAGE

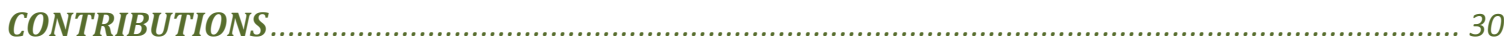

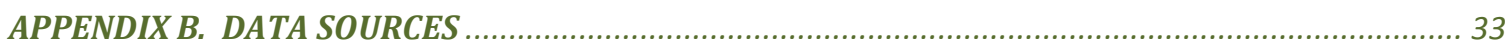

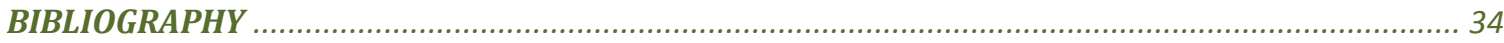

\section{List of tables}

Table 1 Two-Stage-Least-Squares estimation results of the wage bargaining model

Table 2 Actual replacement and unemployment rates 1981-2010

Table 3 Long-term wage responses to productivity, prices, unemployment and the replacement rate

List of figures

Figure 1 Unit labour costs 1975-2010

Figure 2 Wage growth in relation to labour productivity growth 2000-2008

Figure 3 Negotiation power and preference parameter employee

Figure 4 Contributions to wage growth based on the wage bargaining model

Figure 5 Explanatory power of productivity, prices and unemployment for wage growth

Figure 6 Distribution of wage contributions of prices and unemployment

Figure 7 Wage responses to 5\%-point lower replacement rates according to the Error-Correction-Model 
"The relation between wages and productivity is important because it is a key determinant of the standard of living of the employed population as well as of the distribution of income between labour and capital." Martin Feldstein in "Did wages reflect growth in productivity?", 2008

\section{INTRODUCTION}

Wage developments are not easy to explain. In developed and developing economies private sector wages but often also government sector wages are the outcomes of bargaining processes, in which employers and employees usually have a say. In addition to this, government policy matters such as alterations in the tax rates and social security measures. This makes that the ultimate formation of wages does not give an outcome straightforwardly linked to observable determinants. In particular, the direct impact of labour productivity on wages has frequently been the topic in the scientific literature and in policy debates. A high (low) labour productivity growth justifies a high (low) wage growth, but also other factors play a role in the wage negotiation process and push or pull wage growth in most developed economies.

In the European Union, consisting of 27 countries of which 17 countries $^{2}$ form an economic and monetary union (EMU), there are regularly calls for further integration, in the field of political integration but also in the field of economic coordination. In the aftermath of the global financial and economic crisis, the sovereign debt crisis has triggered a discussion on new fiscal discipline in which current account developments are not disregarded. Twin deficits, implying a fiscal and a current account deficit often go hand in hand. In this debate, an important factor influencing the current account balances has been put higher on the EU agenda: wage coordination. In the absence of a functioning fiscal union where fiscal funds can flow from one member country to another in case of asymmetric shocks, wage coordination among member states can be an alternative for adjusting adequately to shocks.

Member states in the monetary union are no longer able to adjust their nominal exchange rate. They can therefore only compete with their real exchange rates where the main adjustment mechanism is the unit labour cost (wage growth minus productivity growth). A moderate development of wages positively affect the current account, in that a lower wage growth is beneficial in terms of international competitiveness and therefore will lead to higher exports and thus on current account balances. Oppositely, countries with abundant wage growth loose in terms of international competitiveness. Their higher wages translate in higher export prices and consequently lower exports of goods and services, and therefore will show a deficit on the goods and services balances of the current account. ${ }^{3}$

Following this way of reasoning, a coordination of the wage growth across the EU countries could partly wipe out the imbalances on the current accounts of the individual countries. Countries with a current account surplus in the recent past (Germany, for instance) would have had a lower surplus in case its

\footnotetext{
2 The member states of the EMU are Austria, Belgium, Cyprus, Estonia (since 1 January 2011), Finland, France, Germany, Greece, Ireland, Italy, Luxembourg, Malta, the Netherlands, Portugal, Slovenia, Slovakia and Spain.

${ }^{3}$ On the systematic divergence of current accounts between countries with surpluses (such as Germany) and countries with deficits (Greece, Spain), see chart 4 of Mongelli and Wyplosz (2008) or the discussion of charts 5-7 in De Grauwe (2011).
} 
wage growth had been less moderate, while countries that had a current account deficit in the recent past (Greece, for instance) would have had a lower deficit in case its wage growth had been less abundant. As the European Union is not a closed economy, a certain degree of current account imbalances will naturally remain, even in case of perfect wage coordination.

Especially for people outside the Europe Union this discussion will be hard to follow. A main question is how several economies, with a common monetary policy, with a certain degree of economic co-operation but with different economic structures could agree on a common wage growth rate. Countries have different unemployment rates, differences in labour productivity growth and different social security systems, and tax rates. Moreover, even in a monetary union, the different member states have different levels of inflation. All these macroeconomic factors can affect to some extent the development of wages. Only in the extreme case that the national authorities could fix the growth rate of wages, a workable coordination of wages across countries could exist. Although the national authorities have a say in government wages and social security benefits, wages in the private sector are in most European countries a bargaining process between employers and labourers or labour unions, where the government has no legal instruments to interfere.

To clarify things, we provide here the precise wording of the Council of the European Union on what was baptised in popular terms the "competitivity pact", officially called the "Euro-Plus Pact" or "Pact for the euro". The relevant paragraph of the Council conclusions (see Council of the European Union, 11 and 25 March 2011) states under the heading foster competitiveness the following:

"Progress will be assessed on the basis of wage and productivity developments and competitiveness adjustment needs. To assess whether wages are evolving in line with productivity, unit labour costs (ULC) will be monitored over a period of time, by comparing with developments in other Euro area countries and in the main comparable trading partners. ... Large and sustained increases may lead to the erosion of competitiveness, especially if combined with a widening current account deficit and declining market shares for exports. Action to raise competitiveness is required in all countries, but particular attention will be paid to those facing major challenges in this respect. ...

Each country will be responsible for the specific policy actions it chooses to foster competitiveness, but the following reforms will be given particular attention:

(i) respecting national traditions of social dialogue and industrial relations, measures to ensure costs developments in line with productivity, such as:

- review the wage setting arrangements, and, where necessary, the degree of centralisation in the bargaining process, and the indexation mechanisms, while maintaining the autonomy of the social partners in the collective bargaining process;

- ensure that wages settlements in the public sector support the competitiveness efforts in the private sector (bearing in mind the important signalling effect of public sector wages). ..."

Close reading of these quotes tells us that wage growth should evolve in line with the growth rate of labour productivity at the national level. As labour productivity growth across countries may diverge, also wage growth across countries diverges. However, wage growth should be conducive for competitiveness, in that large and sustained increases should not occur unless productivity growth is high. Noteworthy is further that nominal instead of real wages are the focal point. Price compensation, implying an indexation of nominal wages on consumer price inflation, should thus not take place according to this pact. As 
previous studies have shown, nominal wage-setting arrangements at the national levels in European countries not only follow labour productivity, they also depend on domestic price developments and the state of the economy. Apart from prices, also unemployment has been a significant determinant of wages in the past.

The main aim of this study is to analyse to what extent other factors than productivity growth determined wage growth in the recent past. In order to put the role of labour productivity in the wage settlement process in perspective, we study the determinants of wage developments at the national level for some European countries over the three decades, from 1980 to 2010. For this purpose, we use a wage bargaining model that takes into account the relevant determinants and that has a rather unique feature in that the wage elasticities with respect to the wage determinants may vary in time. This type of model contrasts the commonly assumed constant elasticities (see for instance Layard et al., 1991).

In our analyses the EU periphery countries Greece, Ireland and Spain are included, as well as Germany, being the EU economy that faced remarkably high current account surpluses even during the recent economic and financial crisis (see Boysen-Hogrefe et al., 2010). Apart from these four European countries, the US is included in the analyses, as it is the largest economy worldwide and the main trading partner of the EU.

We use a non-linear wage equation that determines the model equilibrium following from a theoretical wage bargaining model introduced by Graafland and Huizinga (1999) and investigated before by Peeters and Den Reijer $(2003,2008)$. The non-linear nature of the wage equation enables us to compute unemployment elasticities that can vary over time. Moreover, we quantify the time-varying contributions of the different determinants to the wage increase over the sample period of almost thirty years. We are interested in the determinants that turn out to be dominant during different decades for the different countries. In addition to long-term flexibility, we are also interested in short-term impulse response dynamics to examine differences among the countries.

The paper is organised as follows. Section 2 provides more background information and stylised facts. Section 3 presents the theoretical model and the non-linear wage equation. Section 4 reports the econometric estimates of the wage equation for each of the countries. Using these results, we compute the labour productivity, price and unemployment elasticities and contributions of the determinants with respect to the wage formation. Section 5 examines the downward rigidity of wages. It analyses the recent developments in productivity in combination with price and unemployment developments, along with the degree of nominal wage flexibility in the countries under investigation. Section 6 reflects on some policy issues and section 7 draws the main conclusions. The appendices provide analytical derivations of the wage bargaining model, including the elasticities and wage contributions, and describe the time series used in this paper. Sections 3 and 4 are quite technical, but contain special parts for those readers that are not interested in technicalities but rather prefer to read the economic findings. 


\section{LITERATURE BACKGROUND AND STYLISED FACTS}

While the neoclassical theory assumes that the economy is self-correcting and therefore wages go down in case of excess labour and go up in case of labour shortages, the Keynesian theory is more applicable to the current state of wage setting, especially in developed economies with strong labour unions. As Keynes described in The General Theory on Employment, Interest and Money, workers and unions tend to fight tooth-and-nail against any attempts by employers to reduce money wages (Keynes, 1936). The duration of these fights makes that the rigidity or stickiness of wages holds in the short run and for some countries even in the long run.

Wages are prevalently downward sticky in developed economies, as upwardly adjustments in wages have taken place usually in the course of history, at least in nominal terms. From the theory thus follows that there is an asymmetry in the reaction of wages to the unemployment rate. For this reason, we adapt in this study a non-linear econometric model to explain wages that allows for accounting this asymmetry.

We specify a two-player bargain between a representative employer and a representative employee about the gross wage in a Nash bargaining model. Graafland and Huizinga (1999) introduced this model and applied it empirically to the Netherlands. Peeters and Den Reijer (2001) adjusted it and analysed the effects on wages of the remarkably sharp reduction in unemployment in Ireland, in the Netherlands and in Spain at the end of the 1990s. Peeters and Den Reijer (2008) applied the model later to the French, German, Spanish, Dutch and US labour market for the period 1970-2001. Although prices mainly determined wage growth in the 1970s and 1980s, also labour productivity contributed largely to wage growth in Germany and the United States. In the United States, productivity contributed most to wage growth in the 1990s. In the course of the 1990s up until 2001, the sharp decline of unemployment was the main determinant of wage growth, in particular in Spain.

We now show some stylised facts for the countries under investigation here and focus first on unit labour costs. The period considered is the decade 1975-2010 where we mainly focus on the last decade. For Germany, that was often mentioned and praised for its relatively moderated wage development (see for instance Boysen-Hogrefe, 2010, or De Grauwe, 2011), unit labour costs were low in comparison with the periphery countries Greece, Ireland, Portugal and Spain.

Figure 1 corroborates this. Growth of unit labour costs was on average $0.3 \%$ in Germany in the period 2000-08, while this was at least eight times higher in Greece, Ireland, Portugal and Spain. The US is an intermediate case, as unit labour costs grew on average 2.1\%. In Greece, Ireland, Portugal and Spain, unit labour cost fell sharply in 2009-2010 due to the sovereign debt or banking crisis in their domestic economies. In sharp contrast, a strong acceleration in economic growth entailed a strong rise in unit labour costs in German. The difference between Germany and the others is significant. 
As the growth in unit labour costs equals, by approximation, the nominal wage growth minus the productivity growth, we disentangle it. Figure 2 shows the results. For illustration purposes, the global recession year 2009 is not included as it was exceptional. Nor is the year 2010 included as this was again a recession year for the periphery countries. The figure corroborates once more that Germany differs from the others. It not only follows that German productivity grew faster than German wages in several years during the period 2000-08, but also that productivity growth and wage growth were in a much smaller range in comparison with the other countries. Other than these more "volatile" outcomes for Greece, Ireland, Portugal and Spain, relevant to our analyses is the fact that most data points are far from the $45^{\circ}$ line in the graph. In Greece, Ireland and Portugal and to a lesser extent Spain, wage growth in several years remained very high while productivity growth was relatively low. Greece and Ireland recorded even wage growth of more than $9 \%$ while productivity growth was only $2-3 \%$.

However, having written this, we underline that these are only correlation analyses. We now turn to our wage bargaining model with the aim to estimate causal relationships running from productivity and other factors to wage growth. ${ }^{4}$ This enables us to compute wage elasticities and therewith wage contributions, aiming for insights in the driving forces underlying the wage growth. It will further reveal differences across countries.

\footnotetext{
${ }^{4}$ Another interesting avenue is the causal relationship from productivity to wages. Several theories argue that higher wages push up labour productivity, while others argue that high wage depress labour productivity (see Caballero and Hammour (1996), Fase and Tieman (2001) and Kleinknecht (2003)). It is however beyond the scope of this paper to investigate this further, as our main aim is to investigate the policy suggestions laid down in the introduction and understand the wage growth.
} 
Figure 1 Unit labour costs 1975-2010

in annual growth rates, \%
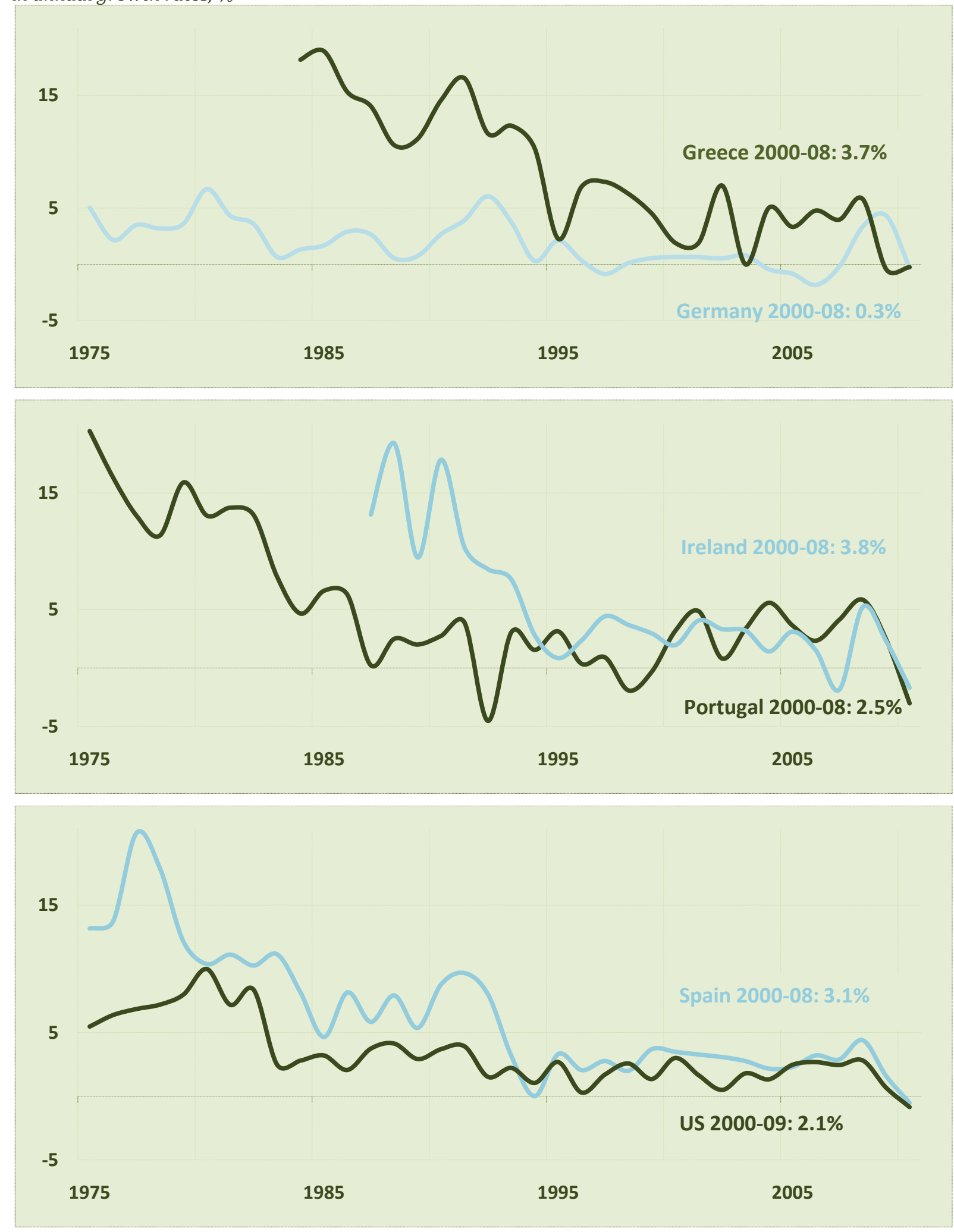

Source: Own calculations based on the KLEM European Commission and OECD databases, see appendix B.

Note: The unit labour cost is the gross hourly wage rate of the whole economy, in euros for Germany, Greece, Ireland, Portugal and Spain and in US dollar for the US, divided by the production per hour. The percentages mentioned for the period 2000-08 are simple averages. 
Figure 2 Wage growth in relation to labour productivity growth 2000-2008 annual \%

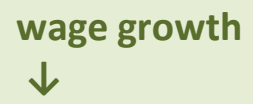

10

Greece

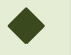

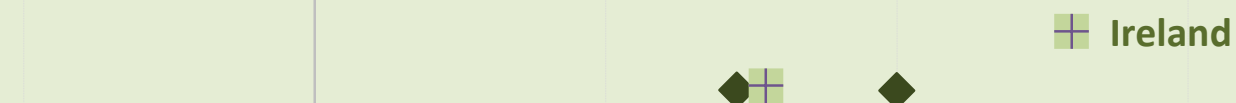

6

4

2
$\triangle$

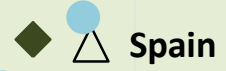<smiles>C1CCCCC1</smiles>
$+$
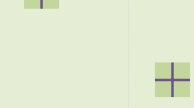

+ US

0

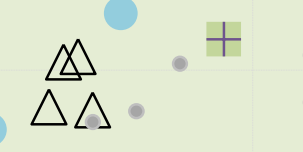

- US

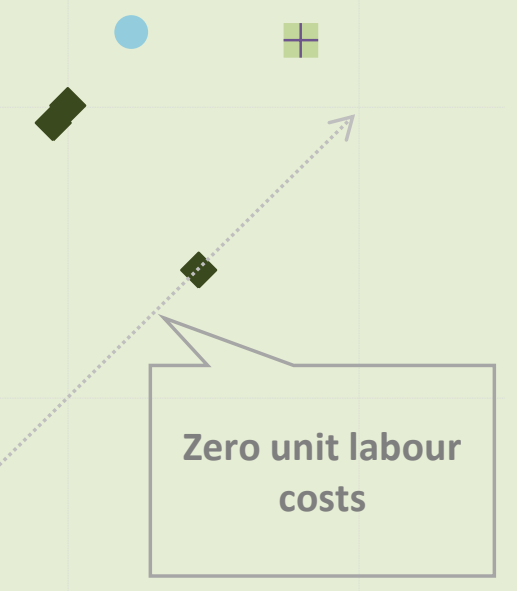

$-2$

0

2

4

6

productivity growth $\rightarrow$

Source: Own calculations based on the KLEM European Commission and OECD databases, see appendix B.

Note: Productivity is measured as real GDP per capita. Data points above the $45^{\circ}$ line correspond with a gross hourly wage rate that is higher than the productivity growth. 


\section{WAGE BARGAINING MODEL}

This section describes the specifications of the two-player bargain between a representative employer and a representative employee about the gross wage in mathematical terms. We start from a profit and a utility maximising function and derive first order conditions that render a wage equation dependent on several factors.

In case you are, as a reader, not interested in the technical details of the econometric model as laid down in the subsection below, you can skip it without loss of economic information. Instead, you can read subsection 2.2 that contains an economic description of the relationships assumed in this study that should be self-explanatory.

\section{i. $\quad$ The wage bargaining model in formulas}

The optimal gross wage of an employee is the wage that maximises the combined objectives of the employer and the employee. It is specified as

$$
\max _{w} \Phi \stackrel{\text { def }}{=} \Pi^{\alpha} \Psi^{1-\alpha}
$$

where $\Pi$ is the profit function of the employer and $\Psi$ the utility function of the employee and $\alpha$ a parameter representing the bargaining power. This bargaining parameter is ranged between 0 and 1 ; the closer it is to 0 the employee has almost full power and the employer almost none during the negotiation process, while a value close to 1 indicates the opposite where the employee hardly has power and the employer almost all. 5

We define profits as net revenues minus labour costs. Gross revenues equal the price $(P)$ times the number of products sold. The price is exogenous. Net revenues, that is gross revenues minus value added taxes and capital costs (interest, depreciation) equal $P^{\omega}$ with $\omega$ a parameter that we will estimate. The number of goods sold differs from the production by the change in inventories. Costs only consist of wage costs that equal the gross wage per employee $W$ times the number of hours worked $L$. The specification of profits per labour hour is therefore

$$
\Pi \stackrel{\text { def }}{=} P^{\omega} q^{\rho}-W
$$

where sales per hour equals $q^{\rho}$ with $q$ being labour productivity. In case $\rho=1$, production equals sales. In case $\rho<1$, labour productivity does not fully translate into an equal increase in sales (cf. Bell et al.,

${ }^{5}$ We interpret this negotiation power also as the value the employer or employee attaches to profits and utility, respectively (see also Figure 3). 
2000). ${ }^{6} \mathrm{~A}$ part of the inventory of goods is devalued or never sold, such as for instance often happens with perishable food products or out-of-date computers or cell phones. The producer price $P$ is exogenous and we allow parameter $\omega$ to deviate from 1. It may also occur that prices do not play a role in the wage determining process, in which case $\omega=0.7$ The representative employer's aim in (2) is the maximisation of profits per employee $\Pi$, by adjusting labour input. A precondition of the maximisation is that the objective function is concave in $W$. We come back to this issue in the empirical analyses.

The employee bargains about the nominal net wage, which consists of the gross wage after deduction of taxes and social contributions, $t$, and considers this in deviation of the reservation wage represented as $W_{\text {reservation: }}$

$$
\Psi \stackrel{\text { def }}{=} W(1-t)-W_{\text {reservation }}
$$

We distinguish an official and an informal sector in the economy. In the official sector people work and earn an official wage $W_{\text {official }}$. People in the informal sector have an informal "opportunity" wage, $W_{\text {informal }}$. The reservation wage, as mentioned in (3), represents the employee's outside opportunity wage or benefit that we define as a weighted average of this official and informal wage,

$$
W_{\text {reservation }} \stackrel{\text { def }}{=} \beta W_{\text {official }}+(1-\beta) W_{\text {informal }} \text {. }
$$

The wage in the official sector equals the after-tax gross average market wage $W(1-t)$ in case of the absence of unemployment $u$, which implies that $u=0$. As another extreme case, in the case of full unemployment $(u=1)$ the official gross wage equals the unemployment benefit, which equals the replacement rate $R$ times the gross wage as, $R * W$, the replacement rate equals the average unemployment benefit divided by the average gross market wage $(0 \leq R \leq 1)$. In sum, we have thus defined the official wage as

$$
W_{\text {official }} \stackrel{\text { def }}{=} u R W(1-t)+(1-u) W(1-t)
$$

The wage obtained in the informal sector depends on the household production function:

\footnotetext{
${ }^{6}$ In the original wage bargaining model of Graafland and Huizinga (1999) but also in Peeters and Den Reijer (2001) constant returns to scale were assumed, implying that $\rho=1$. Empirically, this restriction was later rejected for all countries under investigation (see Peeters and Den Reijer, 2008), for which reason we introduced the flexibility that $\rho$ can deviate from 1 . This parameter could even exceed 1 , as argued by some referees, in which case the optimization of the wage bargaining model would fail due to non-convexity of the objective function. However, yet, we have never found any empirical evidence for this in countries that we analyse (see also our empirical analyses in section 4 here).

7 This model encompasses the case where prices will not affect wages i.e. $\omega=0$, see also equation (7).
} 


$$
W_{\text {informal }} \stackrel{\text { def }}{=} P_{c}^{v}(\gamma q)^{\mu}
$$

The employee addresses in this case his labour productivity to work at home. He avoids expenditures such as the costs of childcare, home cleaning or house maintenance. The informal wage therefore depends on the consumer price $P_{c}$. Parameter $v$ determines to what extent taxes, insurances and possible capital costs have to be paid $(0 \leq v \leq 1)$ while parameter $\mu$ determines to what extent there is a difference between the labour input for household production and the eventual usable production $(0 \leq \mu \leq 1)$. Parameter $\gamma$ takes account of a possible lower labour productivity of the informal vis-à-vis the official sector $(0 \leq \gamma \leq 1)$. In the case where the employee is non-productive at home, that is $\gamma=0$, no wage is earned in the informal sector and therefore $\beta$ in (4) should logically equal 1.

Optimising the profits and utility functions simultaneously, as follows from Appendix A, the optimal wage results as,

$$
\begin{aligned}
\log W= & \rho \log q+\omega \log P+\log \left\{1+\frac{\alpha(1-\beta) \gamma^{\mu}}{1-\alpha} * \frac{P_{c}^{v} q^{\mu-\rho}}{P^{\omega}(1-t)}\right\} \\
& -\log \left\{1+\frac{\alpha}{1-\alpha}[1-\beta(1-u(1-R))]\right\}
\end{aligned}
$$

With

$\alpha=$ parameter indicating the negotiation power of the employer in comparison with the negotiation power of the employee, larger than 0 (employee full power) and lower or equal to 1 (employer full power),

$\beta=$ parameter indicating to what extent the reservation wage equals the official wage in relation to the informal wage, larger than 0 (reservation wage not dependent on official wage) and less than or equal to 1 (reservation wage only depends on official wage)

$\gamma=$ parameter indicating the degree of productivity in the informal versus the market sector, larger than 0 (informal sector does not matter) and lower or equal to 1 (informal sector matters a lot)

$\rho$ =parameter indicating the impact of labour productivity on the wage rate, larger than 0 (no feed-through) and lower or equal to 1 (full feed-through),

$\omega=$ parameter indicating the degree of the price feed-through in wages, giving full price compensation in wages if equal to 1.

$\Psi=$ utility function of the employee,

$\Pi=$ profit function of the employer,

$\Phi=$ combined profit and utility function,

$P=$ price of produced products set by employer,

$P_{c}=$ consumer price,

$q=$ labour productivity, defined as the production in volumes divided by the number of employees,

$R=$ replacement rate, defined as the average unemployment benefit divided by the average market, wage, larger than 0 and lower or equal to 1 ,

$u=$ unemployment rate, larger than 0 and lower or equal to 1 ,

$W=$ gross average wage before taxes,

$W_{\text {informal }}=$ wage in the informal sector,

$W_{\text {official }}=$ wage in the official sector,

$W_{\text {reservation }}=$ reservation wage of the employee. 
In case of wage coordination, implying alignment of wage and productivity growth as discussed in our introduction in this paper, parameter $\rho$ is $\mathrm{crucial}^{8}$. Ideally, it should not exceed one and it should be positive and significant, entailing that decreases in productivity depress wages and increases in productivity push wages upward. Moreover, according to the Euro-Plus Pact it should hold that

$$
\log W=\rho \log q \Leftrightarrow \log u l c=(\rho-1) \log q
$$

where $u l c \stackrel{\text { def }}{=} W / q$ is the unit labour cost. Perfect alignment of wage growth with productivity growth occurs if and only if $\rho=1$. It implies that there are no other explanatory factors in the wage equation (7). This situation will only occur if the negotiation power of the employer is weak $(\alpha \rightarrow 0)$, so that neither unemployment nor the replacement rate plays a role and price compensation does not take place $(\omega=$ $0) .9$

Figure 3 Negotiation power and employee's preference parameter Vertical axis represents $\log \left\{1+\frac{\alpha(1-\beta)}{1-\alpha}\right\}$, see the third term in equation (7)

1

0

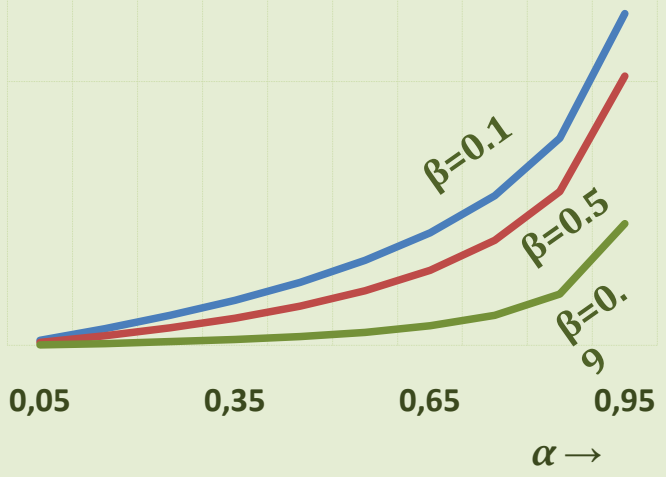

1

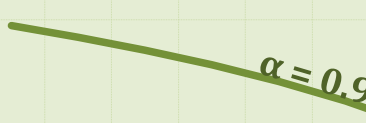

0

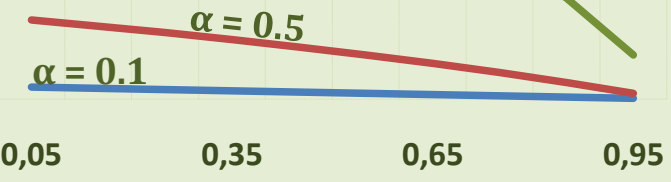

Source: Authors based on the wage bargaining model, see equation (7).

Note: We illustrate the interaction of the negotiation power of the employer versus the negotiation power of the employee, that is $\alpha$ versus $(1-\alpha)$, and the preference parameter of the employee for working in the official sector $(\beta)$ versus working in the informal sector $(1-\beta)$. The left graph shows that a higher preference for working in the informal sector pushes wages up at a given negotiation power, ceteris paribus, because a lower $\beta$ increases the term $\log \left\{1+\frac{\alpha(1-\beta)}{1-\alpha}\right\}$ which is represented at the vertical axis and equivalent to the third term in wage equation (7). The right graph shows that at a given preference of the employee, ceteris paribus, a lower value attached to profits by the employer pushes wages less up than a higher value. In this case unemployment and the replacement rate depress wages less, as follows from the fourth term in wage equation (7) that also contains the factor $\frac{\alpha}{1-\alpha}$. Interesting is further the fact that a small $\beta$ drives up wages fast as the employee's preference for working in the informal sector weakens the power of the employer, who therefore has to pay a higher wage. In contrast, if $\beta$ is close to one, there is hardly a difference in wage increases between a low or a high negotiation power of the employer $(\alpha=0.1$ or $\alpha=0.9$ ), respectively.

\footnotetext{
${ }^{8}$ In the literature more definitions of wage coordination are around, see Acocella and Bartolomeo (2004) or Stockhammer (2008), but we stick strictly to the one specified in equation $\left(7^{*}\right)$ with $\rho=1$.

9 In the case of no negotiating power for the employer, implying $\alpha=0$, the profit function plays no role and the utility function is linear. Therefore the after tax wage of the employee can be unlimited.
} 
The non-linearity of the wage equation (7) allows for non-constant semi-elasticities with respect to the unemployment rate $u$ and the replacement rate $R$. This implies that a wage change in response to a decrease in the unemployment rate of 1\%-point may differ from a wage change in response to an increase in the unemployment rate of 1\%-point, apart from the change in sign. As follows from equation (7), the semi-elasticity with respect to the unemployment rate is negative. Therefore, as expected, a higher unemployment negatively affects wage growth and lower unemployment positively affects wage growth (see equation (A6) in appendix A for the derivation). The extent to which unemployment affects the wage growth depends on the replacement rate $(R)$ and the level of unemployment $(u)$. Ceteris paribus, an increase in unemployment depresses the wage growth more in case of sober unemployment benefits $(R$ is small) than abundant unemployment benefits ( $R$ closer to 1 ). The unemployment elasticity is close to zero in case the replacement rate is close to one. Moreover, the wage elasticity of unemployment is lower if the level of unemployment is higher, implying a lower degree of wage flexibility (see also Folmer, 2009). In sum, wages are more flexibly reacting to changes in unemployment in case of a less generous welfare state of the economy or a tighter labour market. We come back to this feature of the model when we discuss the downward wage rigidities (section 5).

While the wage bargaining equation (7) represents a long-term model equilibrium, our empirical analyses will include also short-term dynamics as the gross wage may deviate from the equilibrium wage in the short term. In the empirical analyses, we therefore estimate Error Correction Model (ECM) specified as

$$
\Delta \log W=\sum_{x_{i} \in\left\{P, P_{c}, q, R, t, u\right\}} \varphi_{i} \log x_{i}+\vartheta\left(\log W_{-1}-\log W_{-1}^{*}\right)
$$

where $\log W^{*}$ equals the non-linear equilibrium (7) at time $t-1$ and $x_{i} \in\left\{P, P_{c}, q, t, u, R\right\}$. We call the parameters $\alpha, \beta, \gamma$ and $\rho$ the deep parameters, that we aim to estimate in the empirical analyses, along with the adjustment speed parameter $\vartheta$ and the short-term effects $\varphi_{i}$ 's. The other determinants in the wage equation, that is the producer price $P$, the consumer price $P_{c}$, the productivity $q$, the tax rate $t$, the unemployment rate $u$ and the replacement rate $R$ are known at the national level in the form of time series.

In the empirical analyses, we also provide the contributions of these determinants to the wage growth. Based on the wage equation (7), we quantify the long-run model contributions of all determinants to the gross wage growth in those analyses,

$$
\Delta \log W^{*}=\sum_{x i \in\left\{P, P_{c}, q, R, t, u\right\}} \epsilon_{x_{i}} \frac{\Delta x_{i}}{x_{i}}
$$

where the elasticity of a determinant $x_{i}$ is defined as

$$
\epsilon_{x_{i}} \stackrel{\text { def }}{=} \frac{\partial \log W^{*}}{\partial \log x_{i}}
$$

or similarly, the multiplication by $\Delta x_{i}$ instead of $\frac{\Delta x_{i}}{x_{i}}$ for the semi-elasticities of $t, u$ and $R$. (see appendix A). 


\section{ii. An economic interpretation of the wage bargaining model}

The wage bargaining model assumes that there is a representative employer that maximises profits and a representative employee that maximises its after tax wage. From the optimisation process, there results a wage rate that is the most optimal from the viewpoints of the employer and the employee. We present the parameter estimates of this wage equation at the national levels, which enables us to calculate the contributions of productivity, unemployment and price to wage growth as presented in section 4 .

A special feature of our model is that the labour productivity does not necessarily feed fully into the wage, implying that a $1 \%$ increase in labour productivity can lead to an increase in the wage of less than $1 \%$. Unlike other studies in the literature, we test for the degree of labour productivity feed-through. The same holds for price compensation. Wage growth does not necessarily compensate price inflation. Further to this, we take into account that an employee has an alternative opportunity than working in the official labour market. The employee can choose between taking part in the labour market and earning the official wage and working in the informal labour market. The latter makes the model more complete than most other labour market models, as there are five main determinants of wages: labour productivity, the consumer price, the unemployment rate, the replacement rate and the average tax rate.

Another special feature of the model is the role of the discrepancy between the official wage and the unemployment benefit. The replacement rate, defined as the ratio of the unemployment benefit and the official wage, plays this role. It has some intuitive implications. A decrease in the replacement rate will depress wage growth. It is thus an interesting policy variable. In times of a tight labour market, policy makers can reduce the unemployment benefit so that the difference of the unemployment benefit and the official market wage widens, in order to moderate wages.

Unlike most other models in the literature, we model wage flexibility explicitly. This makes the analyses more realistic, as the wage contributions of productivity growth, unemployment and price inflation may vary over time in accordance with the real world. Productivity growth and inflation do not have to feed fully into wages. Unemployment reductions can push wages more easily up than unemployment increases depress wages. Rigidities in wages can thus turn out to be stronger down- than upwardly. ${ }^{10}$

\section{ECONOMETRIC ESTIMATION RESULTS}

This section presents the estimation results of the wage bargaining model for Germany, Greece, Ireland, Spain and the United States in subsection 4.i. However, readers not interested in the technical details can skip subsection 4.i and go to subsection 4.ii. This subsection presents the contributions of productivity, prices and unemployment to wages.

${ }^{10}$ Vice versa, upward wage rigidities could be stronger than downward wage rigidities. The probability that this happens at the macro level in the developed economies in our sample is however zero. 
We estimate the model with annual data. The variables represent the whole economy. The sample period is 1980-2010 for Germany and the United States. Although we have a longer full database for these countries, we prefer to align the samples and not to include the 1970s that were characterised by two oil crises en hence a high inflation period. Moreover, in view of the democratic developments in the other countries we stick to the period 1980-2010 or the longest times series available thereafter. In addition, as no consistent up-to-date information on wages is available for Greece for the years 2009-10, we extrapolated these series. ${ }^{11}$

We estimate the wage equation as specified in equation (8), by means of 2-Stage-Least-Squares (2-SLS). In order to correct for endogeneity between the gross wage and the price variables $P$ and $P_{c}$, we employ the instrument variable estimator. The instruments are the three and four year lagged exogenous variables. We follow Peeters and Den Reijer (2008), but have generalised the model by the introduction of three additional parameters. The non-linearity and thus interrelation of parameters has therefore become more complicated. Table 1 reports the estimation results.

Before discussing the estimation results, we describe the road followed for obtaining starting values for the structural or deep parameters in the estimation strategy. These parameters, being the employer-toemployee's negotiating power $\alpha$, the degree of the weight of the official wage in the reservation wage $\beta$, the degree of productivity of the informal sector relative to the official sector $\gamma$, the degree of productivity feed-through $\rho$ and the degree of producer prices feed-through $\omega$, the degree of productivity in the informal sector $\mu$ and the consumer price feed through parameter $v$. We impose all non-linear restrictions according to (7) in the long-run relationship for each of the countries. However, we need suitable starting values for these seven parameters, as the high degree of non-linearity of these parameters can trap us into a local optimum.

For this reason, we search the full grid of possible combinations of $\alpha, \beta, \gamma, \mu$ and $v$ making steps of 0.01 , starting at 0.00 and ending at 1.00. In theory, these parameters should be in this range. We perform the search on the full grid for the maximum value of the objective function for each of the six equations. The productivity parameter and producer price parameter in the long run $(\rho, \omega)$, the adjustment parameter $(\vartheta)$ and the short run parameters $\left(\varphi_{i}\right)$ for the first lag of wages, productivity, prices, unemployment and the replacement rate are estimated freely, if possible . For each combination on this grid the sum of squared residuals (ssr) is calculated. After searching the full grid, we use the combination of these parameters that provides the smallest SSR, along with the associated estimated other parameters, as the starting values in the estimation of the system of equations by 2-SLS. Table 1 presents our results.

\footnotetext{
${ }^{11}$ See appendix A of a description of the database of time series and the previous section for graphs.
} 
Table 1 Two-Stage-Least-Squares estimation results of the wage bargaining model

\begin{tabular}{|c|c|c|c|c|c|c|}
\hline & Germany & Greece & Ireland & Portugal & Spain & US \\
\hline \multicolumn{7}{|c|}{ Long-run parameter estimates } \\
\hline$\alpha$ & 0.68 & 0.82 & 0.83 & 0.74 & 0.88 & 0.68 \\
\hline$\beta$ & 0.84 & 0.89 & 0.77 & 0.85 & 0.89 & 0.89 \\
\hline$\gamma$ & 0.33 & 0.92 & 0.93 & 0.90 & 0.99 & 0.59 \\
\hline$\rho$ & 1.00 & 0.11 & 1.00 & 1.00 & 0 & 1.00 \\
\hline$\omega$ & 0.10 & 0.71 & 0.24 & 1.00 & 0.13 & 1.00 \\
\hline$\mu$ & 0.99 & 0.22 & 0.51 & 0.69 & 0.99 & 0.51 \\
\hline$v$ & 0.99 & 0.14 & 0.51 & 0.11 & 0.20 & 0.61 \\
\hline$\vartheta$ & $\begin{array}{c}-0.20 \\
(-4.05)\end{array}$ & $\begin{array}{c}-0.11 \\
(-6.14)\end{array}$ & $\begin{array}{c}-0.07 \\
(-2.38)\end{array}$ & $\begin{array}{c}-0.35 \\
(-9.09)\end{array}$ & $\begin{array}{c}-0.06 \\
(-4.00)\end{array}$ & $\begin{array}{c}-0.12 \\
(-1.97)\end{array}$ \\
\hline
\end{tabular}

Short-run parameter estimates

\begin{tabular}{|c|c|c|c|c|c|c|}
\hline$\Delta \log W_{-1}$ & $\begin{array}{c}0.33 \\
(3.59)\end{array}$ & & $\begin{array}{c}0.46 \\
(3.71)\end{array}$ & & $\begin{array}{c}0.34 \\
(2.19)\end{array}$ & \\
\hline$\Delta \log q$ & & & & $\begin{array}{c}0.78 \\
(3.42)\end{array}$ & & \\
\hline$\Delta \log P_{c}$ & & & & & & $\begin{array}{c}0.45 \\
(3.70)\end{array}$ \\
\hline constant & $\begin{array}{c}0.04 \\
(6.47)\end{array}$ & $\begin{array}{c}0.14 \\
(12.8)\end{array}$ & $\begin{array}{c}0.04 \\
(3.61)\end{array}$ & $\begin{array}{c}0.13 \\
(8.78)\end{array}$ & $\begin{array}{c}0.06 \\
(3.76)\end{array}$ & $\begin{array}{c}0.04 \\
(4.95)\end{array}$ \\
\hline$R_{a d j}^{2}$ & 0.77 & 0.59 & 0.58 & 0.92 & 0.89 & 0.77 \\
\hline Sample period & $1980-10$ & $1988-10$ & $1981-10$ & $1991-10$ & $1980-10$ & $1980-10$ \\
\hline $\begin{array}{l}\text { Standard } \\
\text { error*100 }\end{array}$ & 1.02 & 3.16 & 2.47 & 1.47 & 1.41 & 0.87 \\
\hline$p$-value $\mathrm{Q}(2)$ & 0.15 & 0.38 & 0.07 & 0.33 & 0.32 & 0.05 \\
\hline $\begin{array}{l}\text { p-value Jarque- } \\
\text { Bera }\end{array}$ & 0.31 & 0.25 & 0.37 & 0.79 & 0.62 & 0.88 \\
\hline Instruments & 13 & 13 & 13 & 13 & 13 & 13 \\
\hline
\end{tabular}


Table 1 shows that adjusted $R^{2}$ varies from 0.58 for Ireland to 0.92 for Portugal. The adjustment parameters of the long-run equilibrium are all significant. Further test statistics on autocorrelation in the residuals (the here presented $Q(2)$ ) as well as on normality of residuals do not reject the hypothesis of autocorrelation and normality at the 5\%-level, respectively. Therefore, the overall estimation results are satisfactory. The productivity parameters for Germany, Ireland, Portugal and the US were insignificantly different from 1 , so they were fixed at 1 . Most of the other parameter estimates in the long run relationship differ across countries. These differences become more apparent when studying the elasticities and wage contributions, which is our next step here below.

\section{ii. Wage growth decomposed into productivity, prices, unemployment and other determinants}

The contributions of the wage determinants show a number of interesting results (see Figure 4). While the beginning of the first decade of the $21^{\text {st }}$ century, like the $1990 \mathrm{~s}$, was marked by much lower inflation than the 1980s, inflation was in most countries still a main contributor to wage growth. Apart from prices, the reduction in unemployment however pushed up wages until the global recession started. In Germany, Portugal, the United States, and in particular in Spain, unemployment played a major role in the wage formation processes. For Germany, Ireland, Spain and the US these results corroborate earlier findings (see also Peeters and Den Reijer (2003, 2008).

Our focus is however on productivity. As the Figure shows, this played a prominent role in Germany, Ireland, Portugal and the United States. Interesting is in this respect the case of Ireland. While productivity growth contributed positively to wage growth in most years, apart from the recession, other factors (prices, unemployment) drove wage growth down. Vice versa, the same holds. In years where productivity was low, other factors (prices, unemployment) pushed wages upward. There is however a large residual part that we cannot explain.

Figure 5 illustrates the relative impact of productivity, unemployment, prices and other factors. It follows that productivity explains wage growth for $40 \%$ in the period 1998-2010. Germany ranks highest in this respect. In Ireland and the US productivity only explained 32 and 28\% of wage growth, respectively, while this was much less for Portugal (18\%), Spain (8\%) and Greece (5\%). Developments in German productivity thus significantly and largely influenced German wages. Nonetheless, developments in unemployment and prices counted in this period for 19 and 12\%. The remainder of 30\% is unexplained. As follows further, in Spain the main wage determinant was unemployment (even at 42\%). Prices counted most in Portugal, Greece and also the US, for more than 35\%. 
Figure 4 Contributions to wage growth based on the wage bargaining model in percentages

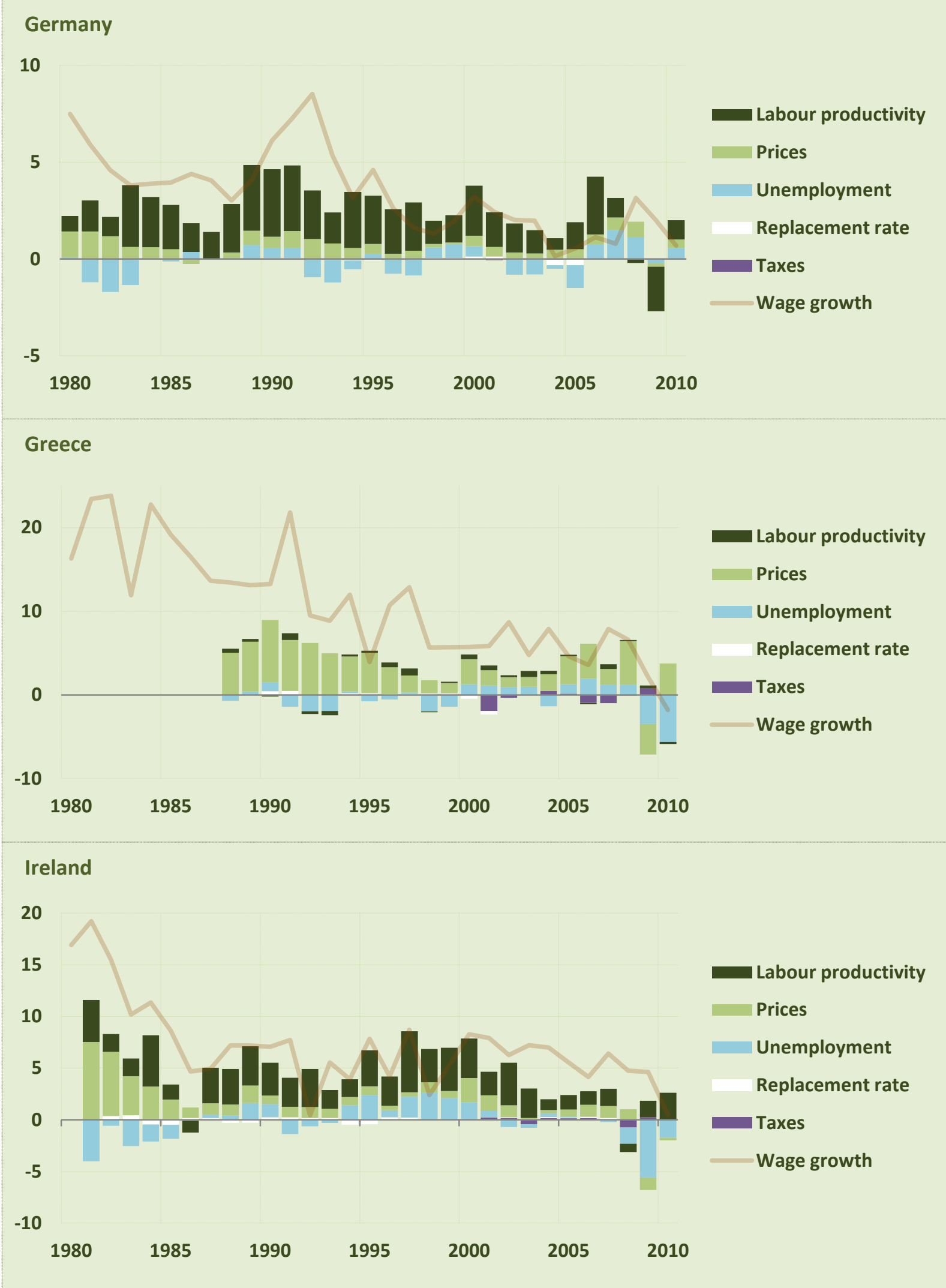

Continues on next page 


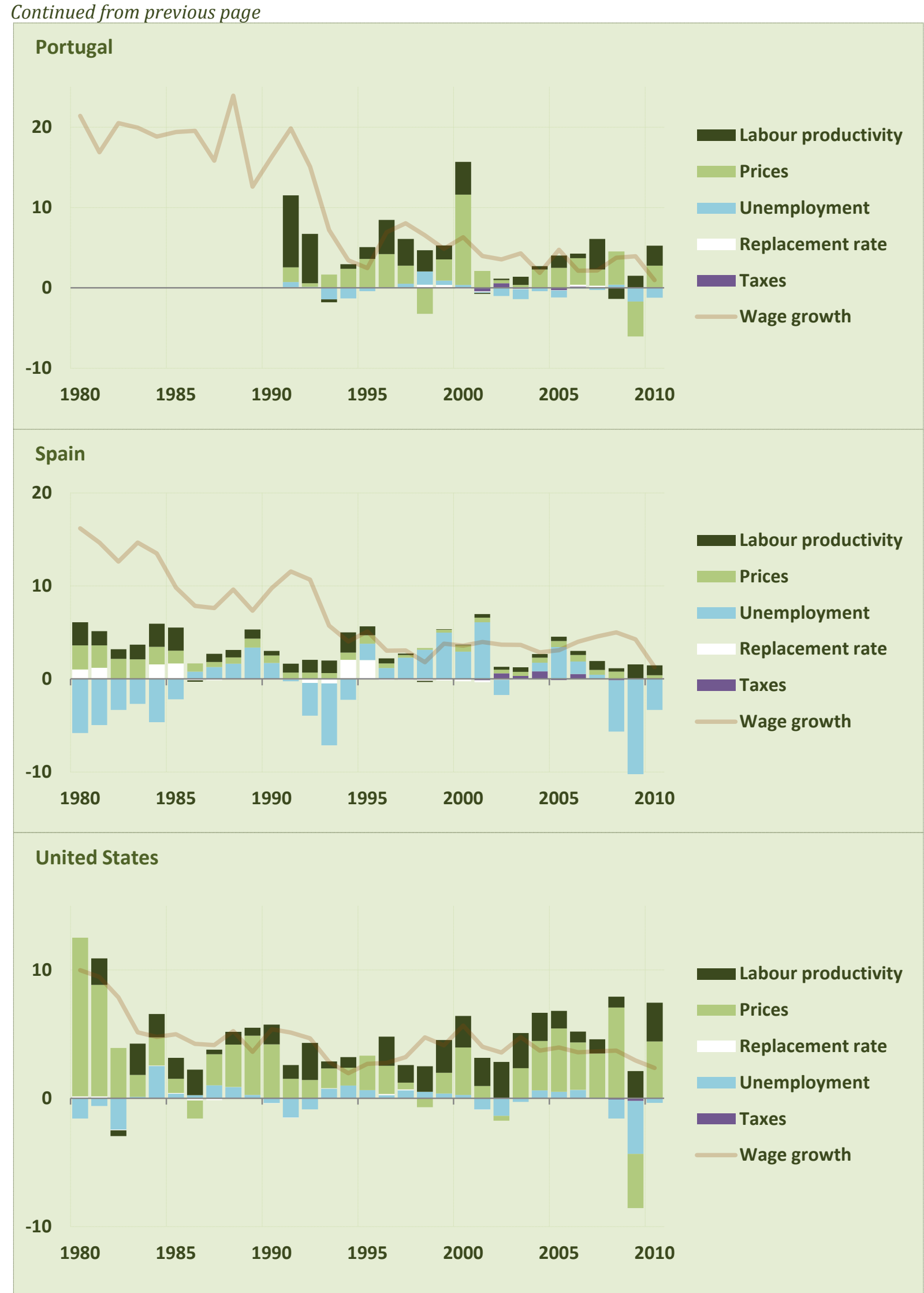

Source: Own calculations based on the econometrically estimated wage bargaining model (see Table 1). 
Figure 5 Explanatory power of productivity, prices and unemployment in percentages of total wage growth

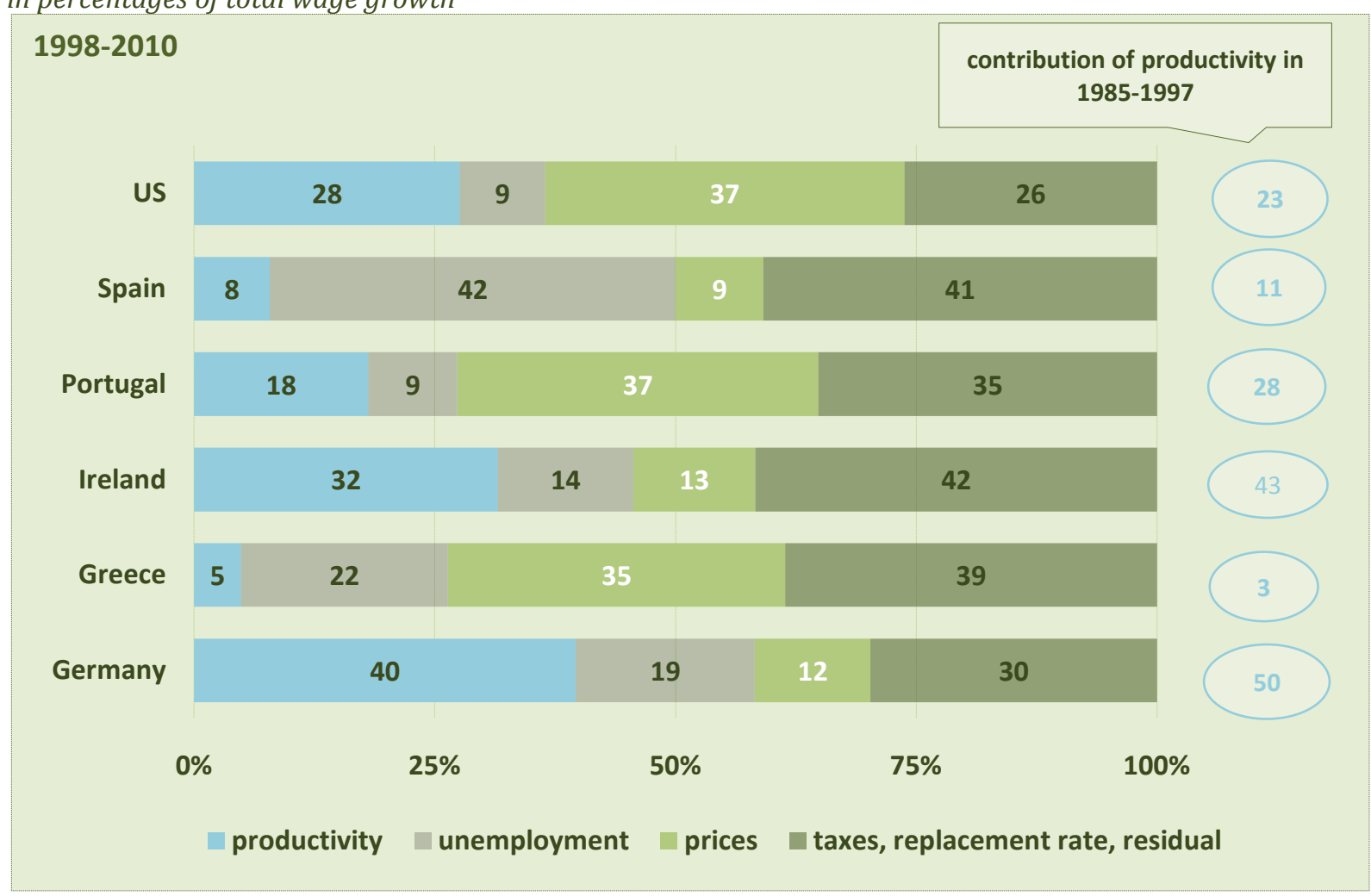

\section{Source: Own calculations.}

Note: For each country and each year we calculated the absolute value of the contribution of productivity (see figure 4) as a percentage of the sum of the absolute value of the contributions of productivity, of prices, of unemployment and of the residual. We calculate the latter as the wage growth minus the contributions of productivity, prices, and unemployment. This graph illustrates the simple averages during the 13 years periods mentioned (from 1998-2010 and 1985-1997). 


\section{LOW PRODUCTIVITY GROWTH AND DOWNWARD WAGE RIGIDITIES}

High wage growth accompanied with low productivity growth, and consequently high unit labour costs, triggered the policy discussion about wages, as referred to in the introduction of this paper. To investigate this further, this section focuses on years where low productivity growth did not drive wage growth down in each of the countries under investigation. We are interested to find out what was hampering the flexibility of wage growth to adjust downwardly.

As the results in the previous section showed, prices and unemployment are important determinants in the wage formation. These factors may have been driving up wages in times of low productivity growth. Positive inflation and low unemployment tend to push up wages. High inflation and low productivity occurred occasionally in Germany, Portugal, Greece and Ireland in the decade 2000-10. From the data also follows that Germany, Portugal, and Greece ran into situations where productivity growth fell below zero, while unemployment decreased which may have put upward pressure on wages.

The extent to which price inflation and the change in unemployment put upward pressure on wages in times of low productivity growth depends on their wage elasticities. We therefore investigate, based on the elasticities computed from the estimated wage bargaining model, the distributions of the contributions of prices and unemployment to wage growth considering the whole sample period. Figure 6 presents the results. It marks the situations where wage growth did not exceed productivity growth by white parts. All other cases are of interest to us here, as wage growth was too high in comparison with labour productivity (not in agreement with the Euro-Plus Pact). The distribution is in frequencies, so for Spain for instance, there were twelve years in which wages dropped more than $1 \%$ due to unemployment and there were thirteen years in which unemployment pushed up wages by more than $1 \%$.

The figure shows that the distribution of the contribution of prices is skewed to the left (implying peaks to the right) in Germany, Greece, Ireland, Portugal, Spain and the US. In many years, inflation pushed up wages more than 1 percent. For the Greece, Ireland, Portugal (apart from one year), Spain and Germany, there are no downward adjustments in wages due to prices, pointing at downward price rigidities. In contrast, the distribution of the unemployment contributions is more symmetric, implying that unemployment not only pushed wages upward but also downward. The degree of flexibility of wages to changes in unemployment was thus relatively high.

We draw two lessons here. First, both prices and unemployment have been driving up wages in times of low productivity and prices did this even more often than unemployment. Second, downward price rigidities exist in Greece, Ireland, Portugal and Spain but also in Germany. Especially in Greece, apart from some rare exceptions, wages even only moved upwardly. This downward rigidity of wages is thus likely to hamper swift falls in wages, also in times of low productivity. 
Figure 6 Distribution of wage contributions of prices and unemployment frequencies counting the number of years

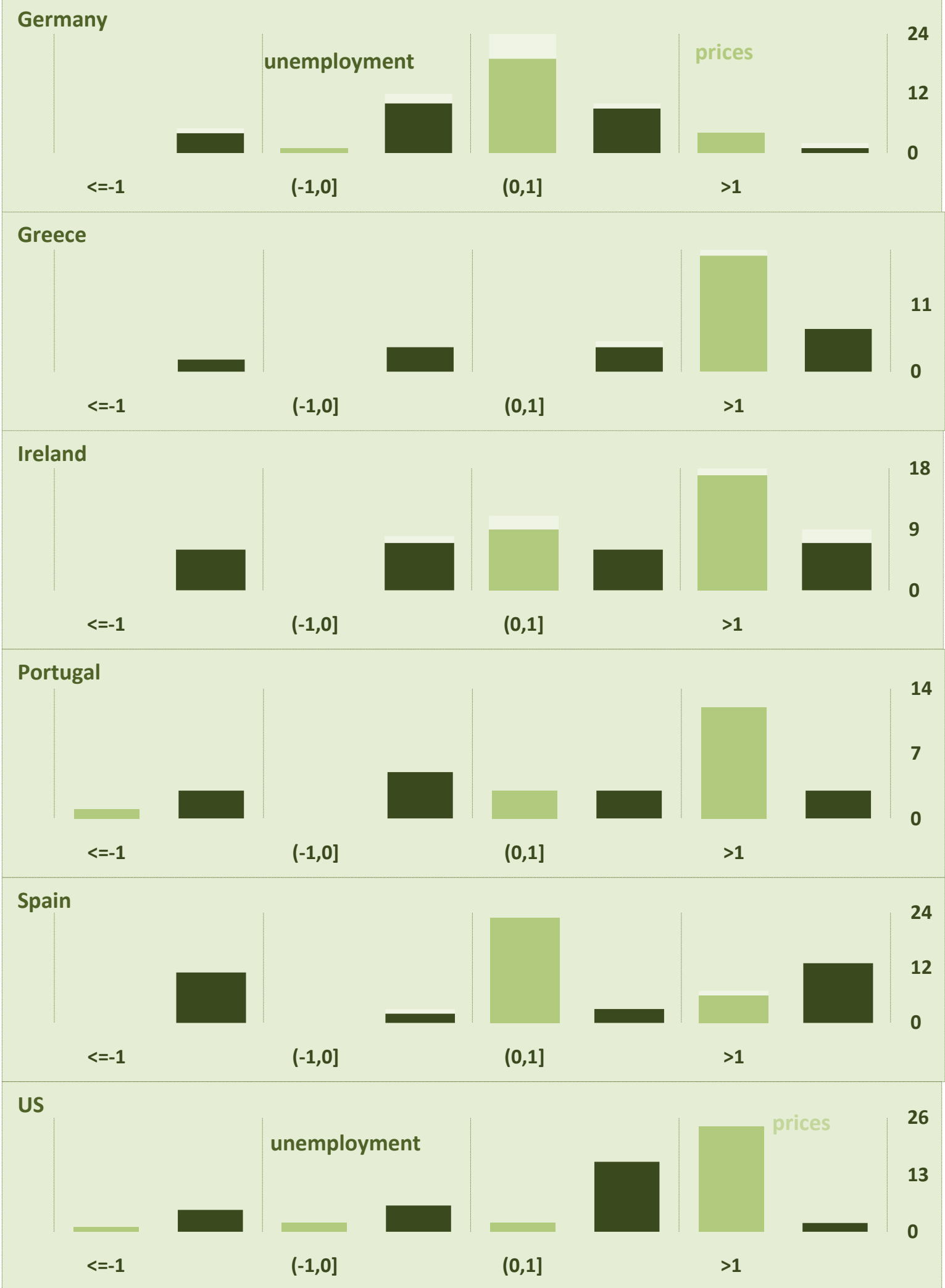

Source: Own calculations based on wage contributions.

Note: White cases mark where wage growth did not exceed productivity growth and consequently unit labour costs fell. Recession years 2009-2010 are not included. 
This downward rigidity in wages, as it concerns the wage responsiveness to changes in consumer price inflation and unemployment enters the wage bargaining model via the reservation wage. There is, among others, the sometimes highly valued informal sector or the high unemployment benefits that makes it unattractive to participate in the labour market. A high reservation wage drives up wages, as the employee wants to have a higher wage to obtain enough utility (see equation (1)). At the same time, the employer is willing to pay this wage, in particular when the labour market is tight, or consumer prices or replacement rates are high (as follows from equation (7)).

Oppositely, a reduction of the reservation wage moderates wage growth. A direct policy instrument to influence the reservation wage is the unemployment benefit, being the nominator of the replacement rate (while the wage is the denominator, see equation (5)). A widening of the gap between the unemployment benefit and the wage rate brings the replacement rate and therewith the reservation wage down as it becomes less financially beneficial to remain unemployed.

While the growth rate of the reservation wage has been lagging somewhat behind the growth rate of the wages during the decade 2000-2007 in Ireland, Portugal and the US, it has kept good pace with the wage growth (see Table 2). Irish reservation wages grew 5.8\%, only 0.4\%-points lower than wages. In the other countries, the reservation wage has followed the wage growth even more closely. In Greece and Spain, the reservation wage grew as fast as wages (with 7.4 and 3.2\%-points, respectively).

The role of the reservation wage is in this respect interesting, in particular for Portugal and Spain, but also Ireland, as these economies record the highest replacement rates (at 41.1, 36.1 and 33.0\%, see Table 2) of this group of economies. In Portugal and Ireland, the reservation wage has even increased 5\%-points in comparison with a decade ago. This contrast sharply with other countries, such as Germany and Greece as they have brought their replacement rates down during this period.

To explain this feature of the model, we analyse the impact of a 5\%-point reduction of the reservation wage on wages with our estimated wage bargaining model (see Table 1). We do this for each of our countries in order to be able to make a comparison of the effects. Figure 7 shows the result. It follows that the impact across the countries varies from a decrease in wages of $0.5 \%$ to even $1.5 \%$ in the longer run. For Portugal and Ireland, for instance, their wages would have been $0.5 \%$ lower in case they would have had replacement rates of 31.1 and 28\%, respectively. This effect would already have materialised in 5 years. The effects for Spain are much bigger. Already in 5 years, wages would have been $0.8 \%$ lower than in the baseline and after 10 years even 1.5\%. The reason that the same policy measure works out differently for the economies comes from the non-linear character of the wage equation that we use and the differences in the estimated employees' preference parameters (see (7)). Lowering the unemployment benefits in a country with a relatively high unemployment, as in Spain, depresses wages more than other countries. Spain recorded 12.1\% unemployment in 2000-10, while Portugal and Ireland recorded respectively $7.4 \%$ and $6.3 \%$ in this period. Reducing replacement rate is thus an effective means for moderating wages and it can help counteracting the upward wage pressure from other determinants. 
Table 2 Actual replacement and unemployment rates 1981-2010

\begin{tabular}{|c|c|c|c|c|c|c|}
\hline & Germany & Greece & Ireland & Portugal & Spain & US \\
\hline \multicolumn{7}{|c|}{ Wage growth and reservation wage growth 2000-2008 } \\
\hline after tax wage $\left(W^{*}(1-t)\right)$ & 1.9 & 7.4 & 6.4 & 3.7 & 3.2 & 4.3 \\
\hline reservation wage ( $\left.W_{\text {reservation }}\right)$ & 2.1 & 7.4 & 5.8 & 3.2 & 3.2 & 4.0 \\
\hline difference & -0.2 & 0.0 & 0.6 & 0.5 & 0.0 & 0.3 \\
\hline \multicolumn{7}{|c|}{ Average actual replacement rate, in percentages } \\
\hline $1981-90$ & 23.6 & 5.7 & 24.3 & 16.7 & 26.3 & 11.0 \\
\hline 1991-00 & 27.1 & 14.6 & 28.9 & 36.9 & 36.1 & 12.5 \\
\hline $2001-07$ & 26.6 & 13.0 & 33.0 & 41.1 & 36.1 & 13.6 \\
\hline \multicolumn{7}{|c|}{ Average actual unemployment, in percentages } \\
\hline $1981-90$ & 7.1 & 7.1 & 14.6 & 7.3 & 18.3 & 7.1 \\
\hline 1991-00 & 8.1 & 10.1 & 11.2 & 5.5 & 19.5 & 5.6 \\
\hline 2001-10 & 8.8 & 9.8 & 6.3 & 7.4 & 12.0 & 6.1 \\
\hline
\end{tabular}

Source: Own calculations and OECD, see appendix $B$.

Note: We calculate the reservation wage according to equation (4), where we use the estimated parameters $\beta, \gamma, \mu$ and $v$ as reported in Table 1. The reported figures are simple averages of the annual growth rates.

Figure 7 Wage responses to 5\%-point lower replacement rates according to the ECM percentage deviation from the baseline

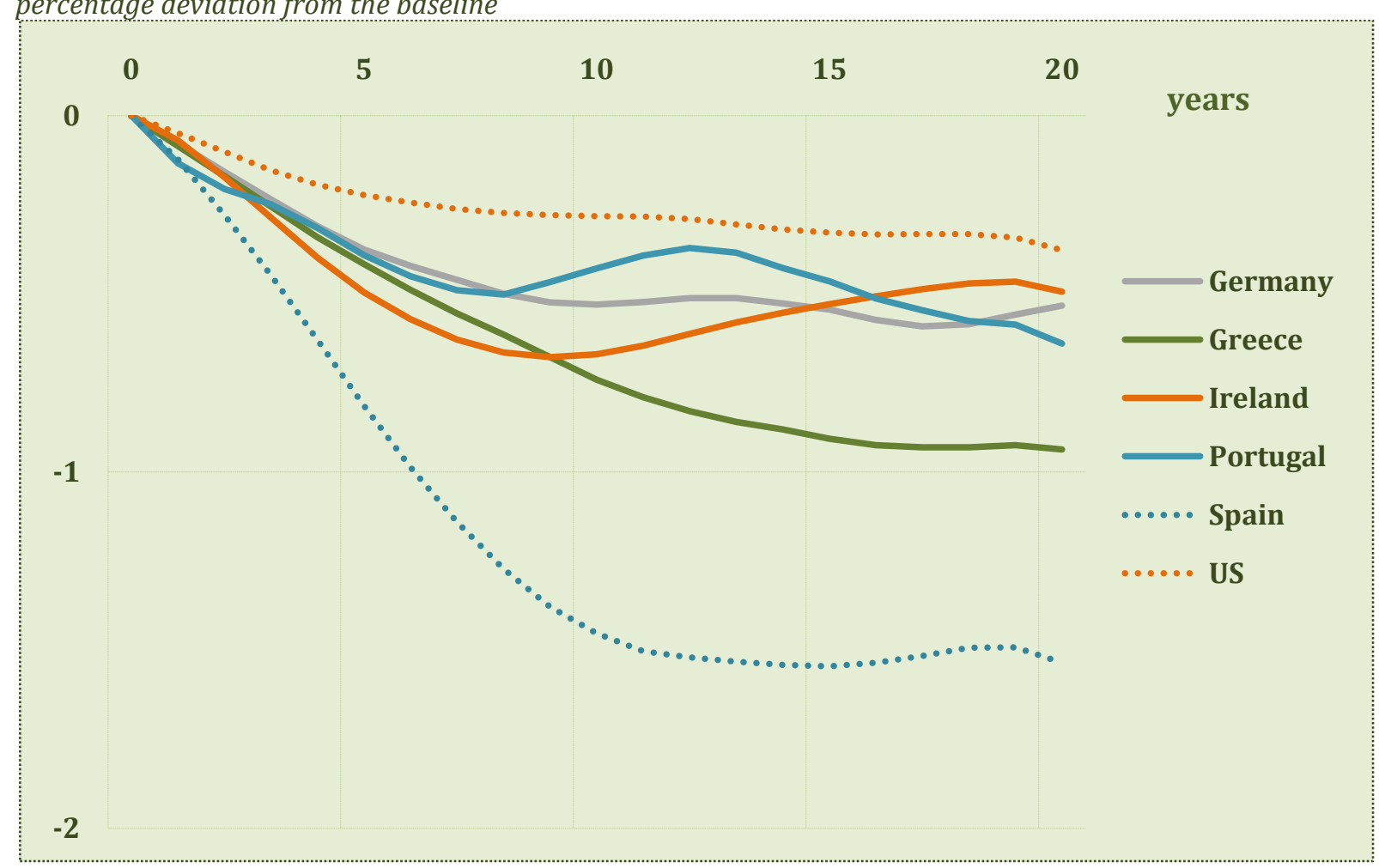

Source: Own calculations based on the wage bargaining model estimates of Table 1.

Note: At time 0 the replacement rate decreases 5\%-points in comparison with the baseline in each country and is kept at that level for the rest of the period (20 years) and the figure presents the wage response according to the Error-Correction-Model equation (8). 
Table 3 Long-term wage response to productivity, prices, unemployment and the replacement rate percentage deviation from the baseline

\begin{tabular}{|c|c|c|c|c|c|c|}
\hline & Germany & Greece & Ireland & Portugal & Spain & US \\
\hline \multicolumn{7}{|c|}{ decrease in productivity of $1 \%$} \\
\hline minimum & -1.00 & -0.14 & -0.71 & -0.87 & -0.47 & -0.90 \\
\hline maximum & -1.00 & -0.16 & -0.74 & -0.93 & -0.59 & -0.93 \\
\hline \multicolumn{7}{|c|}{ decrease in prices of $1 \%$} \\
\hline minimum & -0.24 & -0.45 & -0.39 & -0.62 & -0.16 & -0.92 \\
\hline maximum & -0.29 & -0.56 & -0.40 & -0.80 & -0.17 & -0.94 \\
\hline \multicolumn{7}{|c|}{ increase in unemployment by 1\%-point } \\
\hline minimum & -0.87 & -1.76 & -0.97 & -0.87 & -1.46 & -1.18 \\
\hline maximum & -0.95 & -2.11 & -1.19 & -1.13 & -1.94 & -1.27 \\
\hline \multicolumn{7}{|c|}{ decrease in replacement rate by 5\%-points } \\
\hline minimum & -0.35 & -0.81 & -0.33 & -0.33 & -1.26 & -0.29 \\
\hline maximum & -0.66 & -1.31 & -1.23 & -0.84 & -2.79 & -0.65 \\
\hline
\end{tabular}

Source: Own calculations based on the estimated wage bargaining model (see Table 1).

Note: These estimates are the minimum and maximum of the computed elasticities over the sample periods 1980-2010.

Table 3 presents the long-term wage effects of a 5\% decrease in the replacement rate (see last lines) along with the effect on wages of changes in productivity, prices and unemployment. We present the minimum and maximum of the sample period as these elasticities vary due to the non-linear character of the model. As follows, the range between the minimum and maximum is sometimes quite big. For instance, a decrease of 5\%-points in the replacement rate for Portugal (for example from 41\% to 36\%, see also Table 2 ) could have led to a fall in the Portuguese wage in the long-term ranging from $0.33 \%$ to $0.84 \%$. It effect depends on the timing and in particular on the level of unemployment in Portugal. Comparing the sizes of the wage responses across the determinants shows that the replacement rate is a powerful instrument. In Spain, a $5 \%$ decrease in the replacement rate could have affected wages much more than a $1 \%$ decrease in productivity, a $1 \%$ decrease in prices and it is even larger than a 1\%-point increase in unemployment.

In case we assume that the future wage formation in these countries continues as it happened in the past, these estimated long-term wage responses can be used for taking measures in current and future policy making. 


\section{A POLICY REFLECTION}

Most economists and policy-makers believe that wage flexibility is key issue for Europe, especially a quick adjustment of wages to changes in productivity, prices and unemployment. Flexibility is assumed to allow for a swift recovery of the economy from negative shocks since the latter translate into lower output and higher unemployment. The ambition of EU policy makers to align wage and productivity growth goes however even further. It not only leaves aside the possible influence that the stance of the labour market in terms of unemployment on wages may have. It also rules out that wage indexation takes place. Ignoring prices in the wage bargaining process, implying no adjustment of wages to compensate for inflation, reduces the value of money over time. Abolishing indexation, however, would allow for real wages to decrease and thus reductions in people's purchasing power can take place.

However, the high ambition of European policy makers is understandable in view of the rapidly growing emerging economies outside Europe that keep the competition at the world markets fierce. It is also understandable in light of the persisting fiscal problems in some EU countries and the accompanying current account deficits. Keeping the twin deficits of government balances and current accounts seems not sustainable, nor desirable. Apart from the difficulty to implement wage coordination in practice according to the competitivity or Euro-Plus Pact, such as enforce it on the whole economy while wage bargaining takes mainly place in free market economies at different bargaining levels, the results of this study show that in some countries wage growth is driven by prices and unemployment, rather than productivity. There is thus a need for a different mindset in the wage bargaining process and among workers in particular. In times of low productivity growth and not-low inflation, that may easily occur, the purchasing power of workers risks eroding and therefore bargaining a low wage growth will become difficult.

Alternatively, if productivity growth is not sufficiently high for compensating price increases, measures can be taken to boost productivity. Working more efficiently and effectively, optimizing the input of physical capital combined with labour, and introducing new technological developments, for instance, are ways to increase the production per employee or hour. It may also help to reduce the number of working hours but at the same time employing skilled personnel, matching jobs with the rightly skilled people, and flexibilisation of the labour force. Although this is beyond the scope of this paper, lessons could be learned from those countries that successfully innovated, stimulated and adapted their products traded at the world markets. They have a longer tradition in using wage moderation as a policy instrument not only for the public sector but also for the private sector. 


\section{SUMMARY, CONCLUSION, CONSIDERATIONS FOR FOLLOW-UP}

In most developed countries, the settlement of nominal wages is a complicated process that is not describable in terms of linear equations. Not only labour productivity growth determines wage growth. The stance of the business cycle, the negotiation power of the employees in relation to employers, fiscal and social security measures but also price developments play a role. This paper adopts a wage bargaining model, with the realistic feature of asymmetric and time-varying elasticities of productivity, prices, unemployment, replacement rates. Based on its econometric estimates, we are able to compute the contributions of the different determinants of wages for Germany, the EU-periphery countries Greece, Ireland, Portugal and Spain and the United States. We cover almost the full three decades, 1980-2010 for most of these economies.

The debt crisis in the European Monetary Union has put wage coordination among the member states high on the political agenda. Member states in a monetary union no longer possess the instrument of the exchange rate to adjust to asymmetric shocks. As the countries of the European Monetary Union trade more with each other than with economies outside the union, a coordination of the real exchange seems needed to avoid intra euro area current account imbalances. If not, a low inflation member country with a weak real exchange rate (e.g. Germany) builds current account surpluses with a country with a strong real exchange rate (e.g. Greece). As the real exchange rate only differs in the cost (price) component, being the unit labour costs, the EU leaders have put more emphasis on wage coordination. Wage coordination, defined here as aligning wage growth with productivity growth at the national levels, implies that unit labour costs remain constant. In case each member state of the monetary union sticks to this "pact", the monetary union can absorb asymmetric shocks, potentially without the need to build a fiscal union.

In the Euro-Plus Pact the leaders of the European Union, especially those of the euro area as they are in charge of the European Monetary Union, formulate wage coordination in a strict sense. The main reasoning here is thus that wage growth higher than productivity growth is bad for the competitiveness of the position at the export markets. It implies that unit labour costs are rising and consequently export products and services become too expensive in comparison with those from other countries or continents. As a result, current account balances turn (more) negative and this will not help the countries' public finances. However, vice versa, also countries with decreasing unit labour costs should stick to the pact.

We derive three main conclusions from our analyses in this study.

1. Greece, Ireland, Portugal and Spain are far from aligning wage growth with productivity growth. Although productivity played a role in their wage formation during the period 1998-2010, also prices and unemployment put upward pressure on wages (see Figures 4 and 5). Prices and unemployment played even a more dominant role than productivity in Greece, Portugal and Spain. Unemployment was most dominant in Spain (by 40\%) and prices in Greece and Portugal 
(by around 35\%). Increases in unemployment that put upward pressure on wages, and price inflation kept wage growth high, also in times of low productivity. While increases in unemployment sometimes pushed wages down, this hardly ever occurred for prices. Therefore, downward wage rigidities hampered wages from being moderated (Figure 6).

2. In Germany, also other factors than those that we have explicitly modelled here, must have been depressing German wages. While wage and productivity growth seemed indeed aligned in Germany in the years 2000-2008, and unit labour costs even slightly declined (see our Figures 1 and 2), prices and unemployment still determined wages by 31\% (see Figure 4). Productivity growth contributed $40 \%$ to wage growth. On top of this, there is a large unexplained part of $30 \%$, indicating that fiscal and other factors also played a role in the settlement of wage growth. As earlier results have indicated, a shift in determinants from inflation in the 1970s towards unemployment and productivity in the 1980s and 1990s has taken place but neither price inflation nor unemployment are negligible in wage setting (see also Peeters and Den Reijer, 2008, and Figures 4 and 5 in this paper).

3. Lower reservation wages moderate wages and higher reservation wages push up wages. The replacement rate is a main determinant of the reservation wages. As the replacement rate interacts with unemployment and the preference parameters of the employee between working in the official or informal sector, economies with high unemployment and with a main preference of employees for the official sector can most effectively moderate wages by widening the gap between unemployment benefits and wages (see Figure 7 and equation (A7)). In other words, lowering unemployment benefits moderates wage growth more if unemployment is high $(u$ is high) or if working in the informal sector is unattractive ( $\beta$ is high).

Apart from the macro evidence that we provide in this study, an interesting and relevant avenue of research seems the move towards a more sector level distinguishing between the public and private sector primarily. Wage setting in the public sector is in many developed economies also a bargaining process, though differs in negotiation power from the private sector. In times of implementation of reforms in the public sector, the public sector wage gets under pressure. Econometric models may have to adjust to capture this specific feature, in particular for those countries where the government sector employs a substantial part of the working age population.

Another avenue is the research on fiscal policy on wages. Average and marginal tax rates play a role in wage setting, for employers and employees. As this is an obvious instrument for the national policy makers, studies on the quantified impact of taxes on the wage formation process in the individual countries can help policy makers in making their decisions to pave the way to their national and international objectives. 


\section{APPENDIX A. DERIVATION OF THE WAGE EQUATION, THE WAGE ELASTICITIES AND THE WAGE}

\section{CONTRIBUTIONS}

\section{Ai) Derivation of the wage equation}

Substitution of (2) and (3) in the objective function (1) gives

$$
\Phi=\left(P q^{\rho}-W\right)^{\alpha}\left(W-T(W)-W_{\text {reservation }}\right)^{1-\alpha}
$$

where $T(W)$ is the tax paid by the employee as a function of $W$, and differentiate with respect to $W$ :

$$
\begin{gathered}
\frac{\partial \Phi}{\partial W}=-\alpha\left(P^{\omega} q^{\rho}-W\right)^{\alpha-1}\left(W-T(W)-W_{\text {reservation }}\right)^{1-\alpha} \\
+\left(P^{\omega} q^{\rho}-W\right)^{\alpha}(1-\alpha)\left(W-T(W)-W_{\text {reservation }}\right)^{-\alpha}\left(1-\frac{\partial t}{\partial W}\right)=0 \Leftrightarrow \\
-\alpha\left(W-T(W)-W_{\text {reservation }}\right)+\left(P^{\omega} q^{\rho}-W\right)(1-\alpha)\left(1-t_{m}\right)=0 \Rightarrow \\
W\left\{\alpha \frac{1-t}{1-t_{m}}+(1-\alpha)\right\}=(1-\alpha) P^{\omega} q^{\rho}+\frac{\alpha}{1-t_{m}} W_{\text {reservation }}
\end{gathered}
$$

where $t_{m} \stackrel{\text { def }}{=} \frac{\partial T}{\partial W}$ and $W-T(W)=W(1-t)$.

Substitution of (4) and (5) in (3) gives

$$
W_{\text {reservation }}=W(1-t) \beta[1-u(1-R)]+(1-\beta) P_{c}^{v}(\gamma q)^{\mu} \ldots
$$

Substitution of (A2) into (A1) gives

$$
\begin{gathered}
W\left\{\alpha \frac{1-t}{1-t_{m}}+(1-\alpha)\right\}=(1-\alpha) P^{\omega} q^{\rho}+\frac{\alpha}{1-t_{m}}\left\{W(1-t) \beta[1-u(1-R)]+(1-\beta) P_{c}^{v}(\gamma q)^{\mu}\right\} \Leftrightarrow \\
W\left\{1+\frac{\alpha}{1-\alpha} * \frac{1-t}{1-t_{m}}[1-\beta(1-u(1-R))]\right\}=P^{\omega} q^{\rho}+\frac{\alpha(1-\beta)}{1-\alpha} * \frac{P_{c}^{v}(\gamma q)^{\mu}}{1-t_{m}} \Leftrightarrow \\
\log W=\omega \log P+\rho \log q+\log \left\{1+\frac{\alpha(1-\beta) \gamma^{\mu}}{(1-\alpha)} * \frac{P_{c}^{v} q^{\mu-\rho}}{P^{\omega}\left(1-t_{m}\right)}\right\} \\
-\log \left\{1+\frac{\alpha}{1-\alpha} * \frac{1-t}{1-t_{m}}[1-\beta(1-u(1-R))]\right\}
\end{gathered}
$$

This equals (7) where $t=t_{m}$ is imposed. ${ }^{12}$

12 The lack of consistent time series on marginal tax rates across countries forces us to make this restriction. We leave analyzing the marginal and average tax impact on wages to future research. 
Based on the long-run wage equation the elasticity of wages with respect to productivity, producer and consumer prices, and the semi-elasticities of wages with respect to unemployment and the replacement rate are respectively as follows.

$$
\begin{gathered}
\epsilon_{q} \stackrel{\text { def }}{=} \frac{\partial \log W}{\partial \log q}=\rho+\frac{Y}{X} * \frac{P_{c}^{v}(\mu-\rho) q^{\mu-\rho}}{P^{\omega}} \\
\epsilon_{P} \stackrel{\text { deff }}{=} \frac{\partial \log W}{\partial \log P}=\omega-\omega \frac{Y}{X} * \frac{P_{c}^{v} q^{\mu-\rho}}{P^{\omega}} \\
\in_{P_{c}}^{\stackrel{\text { def }}{=}} \frac{\partial \log W}{\partial \log P_{c}}=v \frac{Y}{X} * \frac{P_{c}^{v} q^{\mu-\rho}}{P^{\omega}}
\end{gathered}
$$

with

$$
X \stackrel{\text { def }}{=} 1+\frac{\alpha(1-\beta) \gamma^{\mu}}{(1-\alpha)(1-t)} * \frac{P_{c}^{v} q^{\mu-\rho}}{P^{\omega}}
$$

and

$$
\begin{gathered}
Y \stackrel{\text { def }}{=} \frac{\alpha(1-\beta) \gamma^{\mu}}{(1-\alpha)(1-t)} \\
\in_{u} \stackrel{\text { def }}{=} \frac{\partial \log W}{\partial u}=-\frac{\alpha}{1-\alpha} \frac{\beta(1-R)}{1+Z}<0
\end{gathered}
$$

and

$$
\epsilon_{R} \stackrel{\text { def }}{=} \frac{\partial \log W}{\partial R}=\frac{\alpha}{1-\alpha} \frac{\beta u}{1+Z}>0
$$

where

$$
Z \stackrel{\text { def }}{=} \frac{\alpha}{1-\alpha}[1-\beta(1-u(1-R))]
$$

All elasticities are time varying, unless specific parameter restrictions hold. For instance, the productivity elasticity (A2) will be non-time varying in case $\rho=\mu$, implying that the final output of labour at work (sold products) is as high as the final output of labour at home. In this case:

$$
\in_{q} \stackrel{\text { def }}{=} \frac{\partial \log W}{\partial \log q}=\rho
$$

Price homogeneity holds in case $\omega=v$, implying that the costs saved by one unity of household work equals the price that the employer earns for one unity of products sold. In this case:

$$
\epsilon_{P}+\epsilon_{P_{c}}=\frac{\partial \log W}{\partial \log P}+\frac{\partial \log W}{\partial \log P_{c}}=\omega
$$


Aiii) Derivation of the wage contributions

It holds that the differential wage equation approximates the sum of the wage contributions, that is

$$
d \log W \stackrel{\text { def }}{=} \sum_{x_{i} \in\left\{P, P_{c}, q, t, u, R\right\}} \frac{\partial \log W}{\partial \log x_{i}} \frac{\partial x_{i}}{x_{i}} \stackrel{\Delta}{\rightarrow} \Delta \log W=\sum_{x_{i} \in\left\{P, P_{c}, q, t, u, R\right\}} \epsilon_{x_{i}} \frac{\Delta x_{i}}{x_{i}}
$$

where in case of semi-elasticities (for $t, u$ and $R$ ) multiplication by $\Delta x_{i}$ instead of $\frac{\Delta x_{i}}{x_{i}}$ takes place.

Figure 4 illustrates the five individual contributions according to the estimated wage equations for each individual country in our analysis. 


\section{APPENDIX B. DATA SOURCES}

The time series used in our analyses are annual and come from the Organisation for Economic Cooperation and Development (OECD, Paris, see http://stats.oecd.org) and the KLEM- and AMECO-databases of DG Economics and Financial Affairs (European Commission, Brussels, see http://www.euklems.net and http://ec.europa.eu/economy finance/ameco). They range from 1970 to 2010 for Germany and the United States. The data range for Greece from 1983 to 2010, for Ireland from 1977 to 2010, for Portugal from 1986 to 2010, for Spain from 1975 to 2010.

Wages $(W)$ are gross, per hour worked for the whole economy in the domestic currency. For the years 1970-2007 they come from the KLEM database (variable LAB_AVG). As these series stop in 2007 (in 2006 for Portugal), we use the gross hourly earnings growth rates of the private sector from the OECD for extrapolating the years up to 2010, except for Ireland and Greece. For Ireland, we use the hourly wages of the manufacturing sector because the private sector data are not available for these years.

Remarkably, the OECD has no hourly wage data for Greece. We therefore use the best alternative, being the Greek compensation for the whole economy from the AMECO database from the European Commission and we divide these by the number of hours worked per Greek employee.

Labour productivity $(q)$ is real growth per hour from the OECD database. We construct an index from these growth rates $(1970=100)$. For those economies for which there is not yet a realisation for 2010 , we use the projection from the Economic Outlook December 2010. The productivity series for Portugal only exists from 1986 onwards.

Producer prices $(P)$ are the total manufacturing producer prices for Ireland and the United States and the domestic manufacturing producer prices for the other countries. All these series are part of the main economic indicators from the OECD. For Portugal, these only exist from 1990 onwards. We use the gross output price index from the KLEM database to estimate the prices for 1986-1989 for Portugal to construct a longer series. This hardly affects our analyses as we use lags for the variables in the econometric estimations.

Consumer prices $\left(P_{c}\right)$ come from the main economic indicators from the OECD.

Unemployment $(u)$ is the harmonised unemployment rate from the macroeconomic indicators of the OECD.

The gross replacement rates (RPR) are two-year annual series from Benefits and wages: OECD Indicators, from the OECD (2007). We interpolated the data for the missing years by using the information for two adjacent years. For each country, we keep the rate for the years after 2008 constant at the rate of 2007.

Tax and social contributions ( $t$ and $t m$ ) are annual data from 2000 onwards from the OECD, while data before 2000 come from EUROMON (see Demertzis et al. 2006).

Our databases and estimation programmes are available upon request. 


\section{BIBLIOGRAPHY}

Acocella, Nicola and Giovanni Bartolomeo, 2004, Is a conservative central banker a (perfect) substitute for wage coordination? Empirica 31(2):281-294.

Addison, John T., Mário Centeno and Pedro Portugal, 2008, Do reservation wages really decline? Some international evidence on the determinants of reservation wages, Banco de Portugal Working Papers 2.

Arpaia, Alfonso and Karl Pichelmann, 2007, Nominal and real wage flexibility in EMU, European Economy Economic Papers no 281.

Barrell, Ray and Karen Dury, 2001, Asymmetric labour markets in a converging Europe: Do differences matter?, European Network of Economic Policy Research Institutes Working Paper 2.

Bell, Brian, Stephen Nickell and Glenda Quintini, 2002, Wage Equations, wage curves and all that, Labour Economics 9(3):341-360.

Bentolila, Samuel and Gilles Saint-Paul, 2003, Explaining movements in the labor share, Contributions to macroeconomics, Berkeley Electronic Press 3(1) article 9.

Bentolila, Samuel, Pierre Cahuc, Juan J. Dolado and Thomas le Barbanchon, 2010, Two-tier labor markets in the great recession : France versus Spain, CEMFI Working paper no 1009.

Borghijs, Alain, Sjef Ederveen and Ruud de Mooij, 2003, European wage coordination: Nightmare or dream to come true?, Central Planning Bureau Discussion Paper no 017.

Boysen-Hogrefe, Jens, Dominik Groll, Wolfgang Lechthaler and Christian Merkl, 2010, The role of labour market institutions in the Great Recession, Applied Economics Quarterly, 61:65-88.

Bover, Olympia, P. García-Perea and P. Portugal, 2000, Labour market outliers: Lessons from Portugal and Spain, Economic Policy, 381-428.

Caballero, R.J. and M.L. Hammour, 1996, On the timing and efficiency of creative destruction, Quarterly Journal of Economics 111(3) 805-52.

Calmfors, Lars, 2001, Macroeconomic policy coordination in the EU: How far should it go?, Swedish Economic Policy Review 8:3-14.

Calmfors, Lars and Åsa Johansson, 2006, Nominal wage flexibility, wage indexation and monetary union, Economic Journal 116:283-308.

Center for Economic Policy Research, 1995, Unemployment: Choices for Europe, Monitoring European Integration 5.

Council of the European Union (Heads of state or government of the euro area meeting), 11 March 2011, Conclusions of the heads of state or government of the euro area of 11 March 2011, Annex 1: A pact for the euro, stronger economic policy coordination for competitiveness and convergence.

De Grauwe, Paul, 2011, The governance of a fragile eurozone, Centre for Economic Policy Studies, Brussels-Belgium, Working Document no 346.

Demertzis, Maria, Peter van Els, Sybille Grob and Marga Peeters, 2006, EUROMON: the multicountry model of De Nederlandsche Bank, DNB Occassional Studies 4(1). 
Destefanis, Sergio and Giuseppe Mastromatteo, 2009, Labor-market performance in the OECD: An assessment of recent evidence, Levy Economics Institute Working Paper no 559.

Dickens, William T., Lorenz Götte, Erica L. Groshen, Steinar Holden, Julián Messina, Mark E. Schweizer, Jarkko Turunen and Melanie E. Ward, 2006, How wages change - Micro evidence from the international wage flexibility project, European Central Bank Discussion Paper no 697. .

Dreger, Christian and Hans-Eggert Reimers, 2011, On the role of sectoral and national components in the wage bargaining process, Regional and Sectoral Economic Studies 11-1.

Fase, Martin M.G. and Alexander Tieman, 2001, Wage moderation, innovation and labour productivity: myths and facts revisited, De Economist 149:115-127.

Feldstein, Martin S. 2008, Did wages reflect growth in productivity? Journal of Policy Modeling, Elsevier, 30(4):591-594.

Folmer, Kees, 2009, Why do macro wage elasticities diverge? A meta analysis, Central Planning Bureau (CPB) Discussion Paper no 122.

Graafland, Johan and Frederik Huizinga, 1999, Taxes and benefits in a non-linear wage equation, De Economist 147(1):39-54.

Grubb, Dennis, Richard Jackman and Richard Layard, 1983, Wage rigidity and unemployment in OECD countries, European Economic Review, 21, 11-39.

Grüner, Hans Peter and Carsten Hefeker, 1999, How will EMU affect inflation and unemployment in Europe? Scandinavian Journal of Economics, 101(1), 33-47.

Guisan, Maria-Carmen and Eva Aguayo, 2007, Wages, productivity and human capital in the European Union: Econometric models and comparison with the USA 1985-2005, Applied Econometrics and International Development vol 7(1).

and Maria Teresa Cancelo, 2006, Employment and productivity in the European Union and comparison with the USA 1985-2005: An analysis of France, Germany, Italy, Spain and the United Kingdom, Applied Econometrics and International Developmentl 6(3):55-63.

Hogen, Vincent, 1999, The determinants of the reservation wage, Centre for Economic Research Working Paper Series 16.

Holden, Steinar and Frederik Wulfsberg, 2008, Downward nominal wage rigidity in the OECD, The B.E. Journal of Macroeconomics, Berkley Electronic Press, 8(1).

Keynes, John M., 1936, The general theory of employment, interest and money, Macmillan Cambridge University Press.

Kleinknecht, Alfred, 2003, Causes of the Dutch job miracle: There is no free lunch!, De Economist $151329-333$.

Layard, Richard, Stephan Nickell and Richard Jackman, 1991, Unemployment: Macroeconomic Performance and the Labour Market, Oxford: Oxford University Press.

Martin, John P., 1996, Measures of replacement rates for the purpose of international comparisons: A note, OECD Economic Studies no 26. 
Mastromatteo, Giuseppe and Sergio Destefanis, 2006, Inequality and labour-market performance: A survey beyond an elusive trade-off, University of Salerno Dipartimento di Scienze Economiche e Statistiche Working Paper no 3.176.

Nickell, Stephen and Sushil B. Wadhwani, 1990, Insider forces and wage determination, Economic Journal 100(401):496-509.

Nickell, Stephen, 1997, Unemployment and labor market rigidities: Europe versus North America, Journal of Economic Perspectives 11(3):55-74.

Peeters, Marga and Ard Den Reijer, 2001, On wage formation, wage development and unemployment: The case of Spain, Ireland and the Netherlands, Econometric Research and Special Studies Department Research Memorandum No 677, De Nederlandsche Bank.

2008, On wage formation, wage development and flexibility: A comparison between European countries and the United States, Applied Econometrics and International Development, 8(1):59-74.

Pichelmann, Karl, 2001, Monitoring wage developments in EMU, Empirica, 28:353-373.

Prasad, Eswar, 2004, What determines the reservation wage of unemployed workers? New evidence of German micro data. in Institutions and wage formation in the new Europe, eds. Gabriel Fagan, Francesco Mongelli and Julian Morgan (Edward Elgar).

Stockhammer, Engelbert, 2008, Wage flexibility or wage coordination? Economic policy implications of the wage led demand regime in the euro area, Intervention - European Journal of Economics and Economic Policies 5(1):54-62.

Van der Welle, Adriaan J. and Frank A.G. den Butter, 2005, Labour market flexibility in the EMU: a policy oriented literature overview (in Dutch: Arbeidsmarktflexibiliteit in de EMU: een beleidsgericht literatuuroverzicht), Kwartaalschrift Economie 4:404-428.

Vanthoor, Wim F.V., 1996, European Monetary Union since 1848 - A political and historical analysis, Edgar Elgar. 